TITLE:

\title{
A NEW SPECIES OF THE RARE SHELLED SACOGLOSSAN GENUS CYLINDROBULLA FROM MIDDLE JAPAN (OPISTHOBRANCHIATA)
}

\section{AUTHOR(S):}

Hamatani, Iwao

\section{CITATION:}

Hamatani, Iwao. A NEW SPECIES OF THE RARE SHELLED SACOGLOSSAN GENUS

CYLINDROBULLA FROM MIDDLE JAPAN (OPISTHOBRANCHIATA). PUBLICATIONS OF THE SETO MARINE BIOLOGICAL LABORATORY 1969, 17(3): 171-174

ISSUE DATE:

1969-11-29

URL:

http://hdl.handle.net/2433/175595

RIGHT: 


\title{
A NEW SPECIES OF THE RARE SHELLED SACOGLOSSAN GENUS CYLINDROBULLA FROM MIDDLE JAPAN (OPISTHOBRANCHIATA $)^{1)}$
}

\author{
IWAO HAMATANI \\ Biological Laboratory, Tennōji Senior High School attached to \\ Osaka Kyōiku University, Ōsaka
}

With Plates V-VI and 1 Text-figure

In April, 1968, the author collected 6 specimens of a shelled sacoglossan opisthobranch from the Caulerpa colony growing in the lower intertidal zone at Cape Shionomisaki in the province of Kii, Middle Japan. At the same locality, again one more specimen was collected by the author on June 14, 1968. These animals were identified to be a new species belonging to the very rare genus Cylindrobulla Fischer, 1856.

Hitherto, any species of this genus have been unknown around Japan, although up to six species are described in the world. Those species listed below are, however, known merely by their shell, and their descriptions were made all long ago in the preceding century.
C. beaui FISGHER, 1856
C. fragilis (JEFFREYS, 1856)
(West Indies)
C. fischeri Adams \& Angas, 1864
(Italy, Spain)
C. souverbiei (MONTROUzIER, 1874)
(South Australia)
C. sculpta NEvilL, 1869
(New Caledonia)
C. pusilla NeviLL, 1869
(Ceylon)
(Ceylon)

Further, the anatomical study was done recently in detail by MARcus and Marqus (1956) on Cylindrobulla sp. (species unidentified) found near Santos, Brazil.

Here, the specific features of this new species are given as a preliminary account.

The author expresses his thanks to Drs. Huzio Utinomi and Takasi Tokioka of the Seto Marine Biological Laboratory, who have given him facilities for the present study and for publishing the present paper. Especially, Dr. T. Tokioka has kindly read the manuscript. Also his thanks are due to Dr. Kikutarō BABA for the constant guidance and incessant encouragement throughout the course of this work.

1) Contributions from the Seto Marine Biological Laboratory, No. 510 .

Publ. Seto Mar. Biol. Lab., XVII (3), 171-174, 1969. (Article 7) 


\section{Cylindrobulla japonica sp. nov.}

(Japanese name: Iwazutabudogai n.n.)

Holotype: Found on the groups of a green alga, Caulerpa brachypus Harvey, in the intertidal zone near the low water mark in the vicinity of Cape Shionomisaki, Kii on April 28, 1968. For further observations it was fixed together with paratypes by $4 \%$ formaldehyde, preserved in $70 \%$ alcohol, and it is now in the custody of the present author.

Paratype: Sp. Nos. 1-5 were collected together with the holotype. Sp. No. 1 was dissected for the studies of radular teeth and adult shell, Sp. No. 2 also dissected for radular teeth and protoconch, while Nos. 3-5 were provided for future studies.

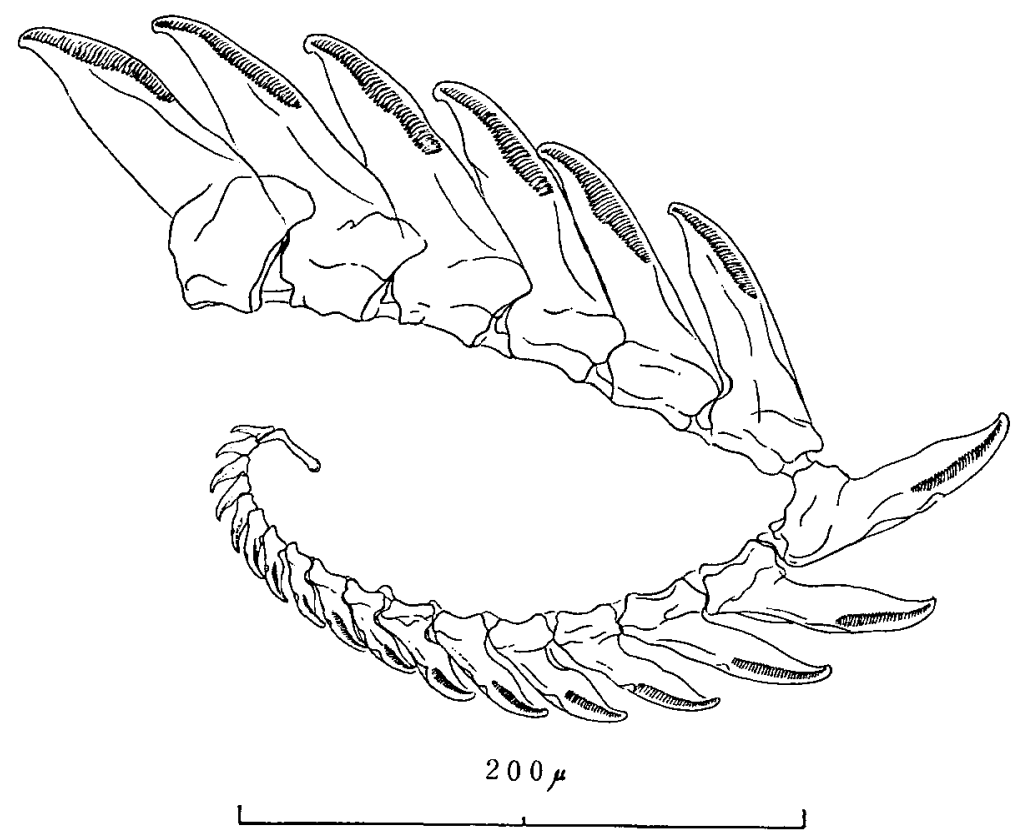

Fig. 1. Cylindrobulla japonica sp. nov. Whole radular teeth of paratype Sp. No. 1 .

Description: The holotype is less than $10 \mathrm{~mm}$ in length in a living extended state. The whole body can be retracted completely into the shell. The head, cephalic shield, is rather large and attains about $4 \mathrm{~mm}$ long. It is characterized, as already mentioned by MArcus and MArcus (1956) (see also BABA, 1966, p. 201), by having a deep median furrow on dorsal, which is more pronounced posteriorly and divides the head into two lateral parts nearly touching each other anteriorly but considerably apart from each other posteriorly. In a full extended state, a slender neck is discernible distinctly between the head-shield and the shell. The foot is rather 
small, as large as the head-shield, and rounded on both the anterior and posterior ends. The whole surface of the body stretched out of the shell is whitish and dotted densely with opaque white pigments with a yellowish tint. The yellowish-orange liver-mass is visible through the thin shell at the posterior end of the visceral sac, and a belt of gill-folds runs diagonally on the liver-mass from the right middle to the left posterior third of the shell. Posterior to the gill-folds and on the liver-mass, numerous opaque white dots are seen through the shell, probably they are hypobranchial glands (as in Berthelina, BABA, 1961, p. 43; Volvatella, BABA, 1966, p. 199; and Cylindrobulla, Marcus and Marcus, 1956, p. 119). The paired eyes are invisible on the dorsal surface, though they are discernible as ivory black points deep in the tissue approximately at the anterior third of respective lateral body sides between the shield and the foot. The seminal groove is observed on the right side of the body extending from the male papilla inside the shell to the genital opening near the middle of the above-mentioned lateral body side.

The shell is almost cylindrical in shape, very thin and a little flexible, but extremely fragile. It is rather bulloid as compared with those of other species of the genus. In live and fully extended specimen the shell looks slenderer than in the empty state, owing to the contraction of adductor muscle; in the holotype $5.7 \mathrm{~mm}$ long, in the paratype Sp. No. $14.75 \mathrm{~mm}$ long and $2.5 \mathrm{~mm}$ broad. In live specimens the shell looks yellowish orange because of the visceral organs seen through it, although the shell itself is calcified only slightly, translucent and whitish in colour. The aperture assumes a narrow slit running straight from the top to the base of the shell and nearly as long as the shell. The anterior third of the outer lip is extended to form a large round opening with a unique slight concavity on the truncate anterior margin. The aperture continues at the top to a narrow sutural slit which coils dextrally about $1 \& 4 / 5$ times in the holotype. The spire is totally sunken to the bottom of the apical umbilicus which is bordered by the inner lip forming a sutural slit. The protoconch is retained at the centre of spire.

The radular teeth is uniserial and of a typical sacoglossan style (as in Cylindrobulla sp., Marcus and Margus, 1956, p. 122 and P1. 1, fig. 8; as in Cylindrobullidae, BabA, 1966, p. 201). The radula of paratype Sp. No. 1 consists of 6 teeth in the ascending series and 18 teeth in the descending series. The last of the latter is rod-shaped with a bent distal end, and this unique teeth is probably formed in some earlier stage just after metamorphosis and is corresponding to the so-called "pre-radular tooth" mentioned by EDMunds (1963, p. 735 and fig. 4, a) on Berthelinia caribbea and other species. Each tooth is very similar to that of members of the genus Volvatella (as in V. vigourouxi, BABA, 1966, p. 199, fig. 9 in P1. 9 and in V. ficula, BuRN, 1966, p. 50, fig. 14). It is blade-like in shape and with a series of about 30 slender denticles on an average (more than 50 at the maximum and less than 10 at the minimum) on each side of the blade, but in the present species there are a series of very faint mill near the middle of each lateral edge just behind the row of denticles. In addition, this species 
differs from members of the genus Volvatella in that the tooth is somewhat broader and a pre-radular tooth mentioned above is present.

Remarks: The shell of the present species is very similar to that of $C$. beaui, but the former is somewhat bulloid and whitish in colour. Moreover the habitats of respective species are far apart from each other. It is very desirable that some live specimens of $C$. beaui are studied in future as to its living state and anatomical points to make a comparison with the present new species possible.

\section{LITERATURE CITED}

Adams, A. \& ANGAS, G.F. 1864. Descriptions of new species of shells, chiefly from Australia, in the collection of Mr. ANGAs. P.Z.S.

Angas, G.F. 1865. On the marine molluscan fauna of the province of South Australia: with a list of all the species known up to the present time; together with remarks on their habitats and distribution, etc. P.Z.S.

$\mathrm{BABA}_{\mathrm{A}}, \mathrm{K}$. 1966. Gross anatomy of the specimens of the shelled sacoglossan Volvatella (=Arthessa) collected from Okino-Erabu Island, Southern Kyasha, Japan (Nudibranchia). Publ. Seto Mar. Biol. Lab., vol. 14, no. 3.

Burn, R. 1966. The opisthobranchs of a Caulerpan microfauna from Fiji. Proc. Malac. Soc. London, vol. 37.

Edmunds, M. 1963. Berthelinia caribbea n. sp., a bivalved gastropod from the West Atlantic. Journ. Linn. Soc. London, Zool., vol. 44, no. 302.

Fischer, P. 1856. Descriptions d'espèces nouvelles. Journ. de Conchyl. vol. 5. (quoted through PILSBRY, 1894)

Jefrreys, J.D. 1856. On the marine Testacea of the Piedmontese Coast. Ann. Mag. Nat. Hist., vol. 17.

- 1882. Notes on the Mollusca procured by the Italian Exploration of the Mediterranean in 1881. Ann. Mag. Nat. Hist., vol. 10.

Marcus, Ev. \& Marcus, Er. 1956. On the tectibranch gastropod Cylindrobulla. Ann. Acad. Brasil. Cien., vol. 28, no. 1.

Nevill, G. \& Nevili, H. 1869. On some new marine gastropoda from the southern province of Ceylon. Journ. Asiat. Soc. Bengal, vol. 38. (Quoted through PiLsBry, 1894)

Pilsbry, H.A. 1894. Manual of Conchology, vol. 15. Opisthobranchiata.

Souverbie, S. M. \& Montrouzier, R.P. 1874. Descriptions d'espèces nouvelles de l'Archipe] Calédonien. Journ. de Conchyl., vol. 22.

\section{EXPLANATION OF PLATES V AND VI}

Plate V Cylindrobulla japonica sp. nov.

Figs. A-E. Living holotype, seen from different sides. (A \& C, dorsal; B \& D, lateral; E, ventral) Fig. F. A part of the group of Caulerpa brachypus HAR VEy, from which the new slugs were collected.

Fig. G. Radular teeth of paratype Sp. No. 1, shown in text-figure 1.

Fig. H. Three teeth of ascending series of the radula shown in Fig. G.

Plate VI Cylindrobulla japonica sp. nov.

Fig. 1. Dorsal aspect of live holotype.

Figs. 2-3. Empty shell of paratype Sp. No. 1. (2, ventral; 3, dorsal)

Fig. 4. Protoconch of paratype Sp. No. 1.

Fig. 5. A tooth from paratype Sp. No. 2, dorsal side.

Fig. 6. A tooth from paratype Sp. No. 1, lateral side.

Fig. 7. A part of descending series of radula of paratype Sp. No. 1 to show a "pre-radular tooth" (P). 
Publ. Seto Mar. Biol. Lab., XVII (3), 1969. Plate V
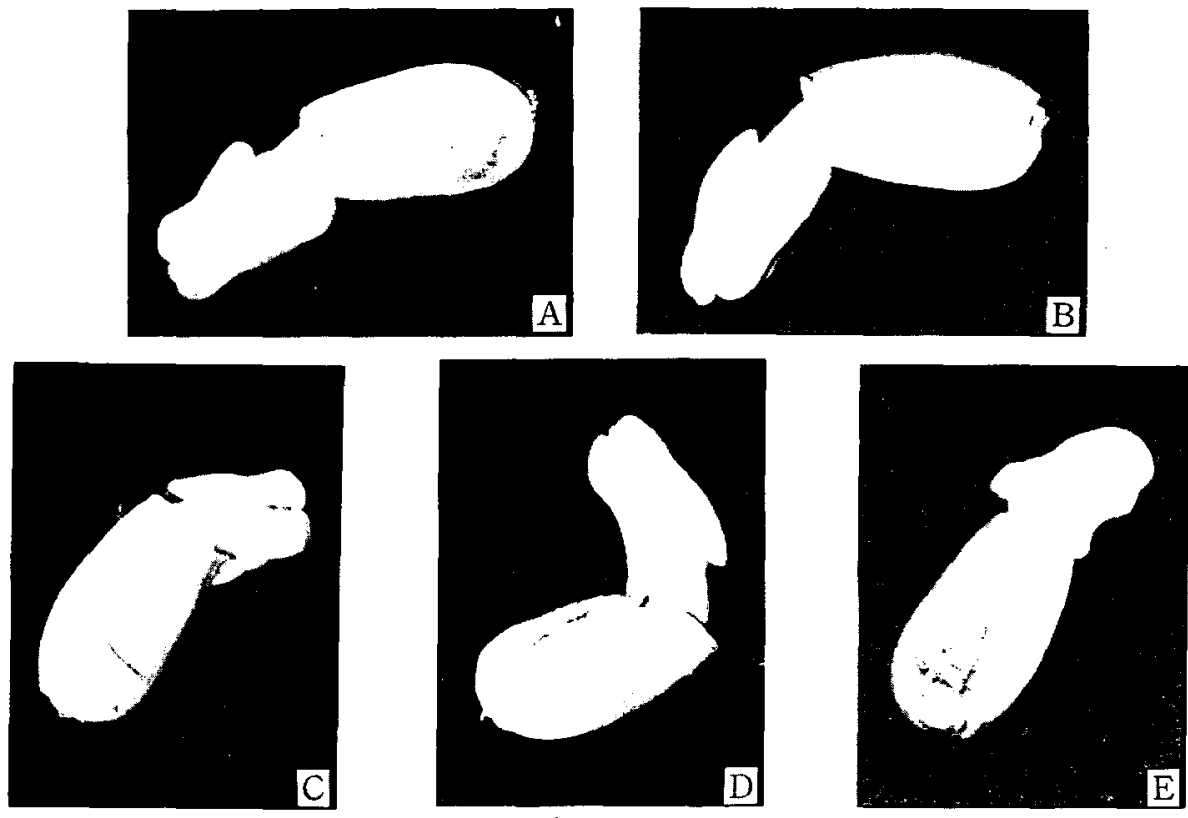

$5 \mathrm{~mm}$
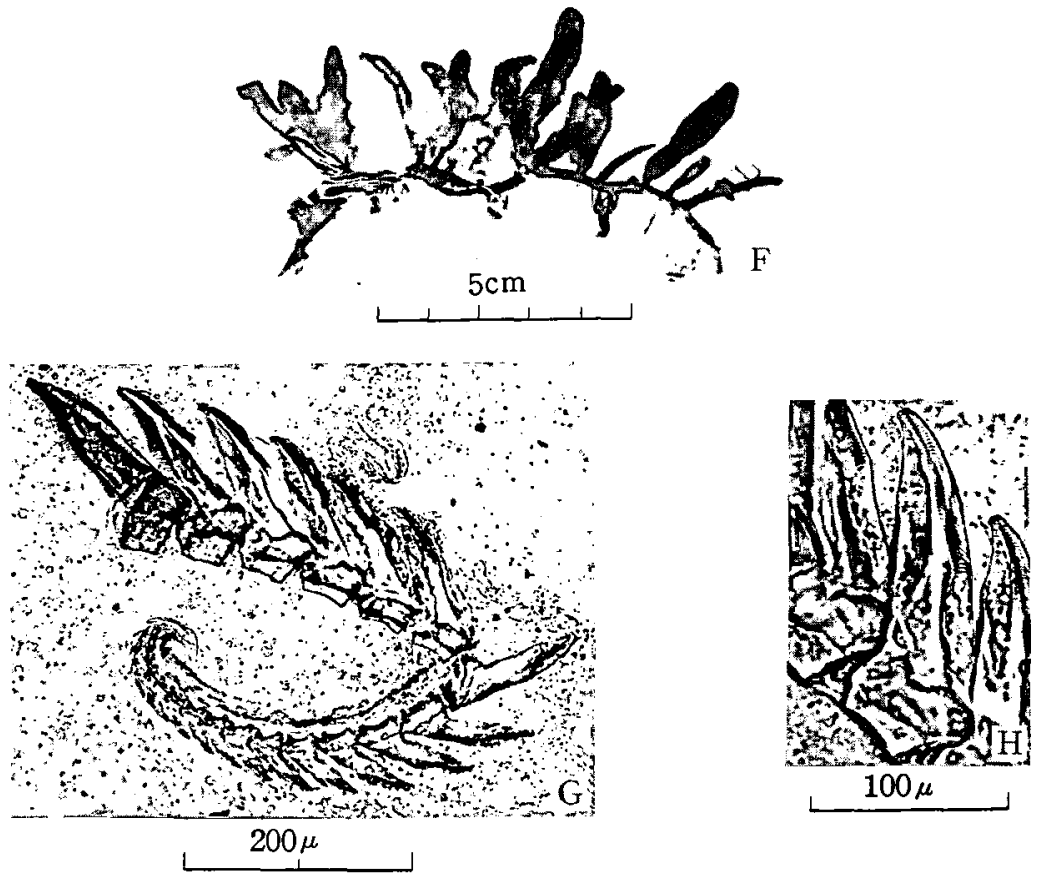

I. Hamatani: A New Shelled Sacoglossan 
Publ. Seto Mar. Biol. Lab., XVII (3), 1969.
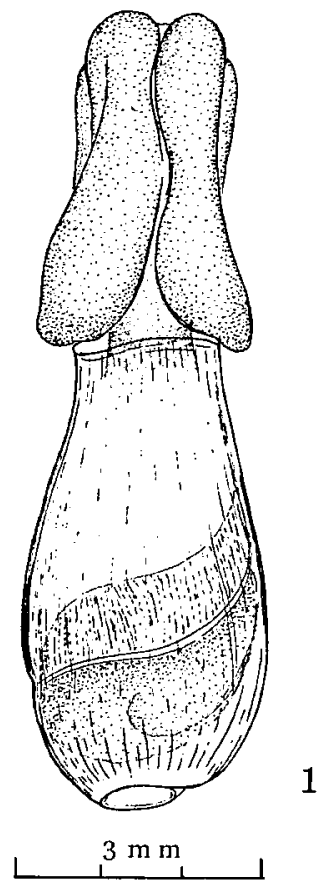

\section{1}
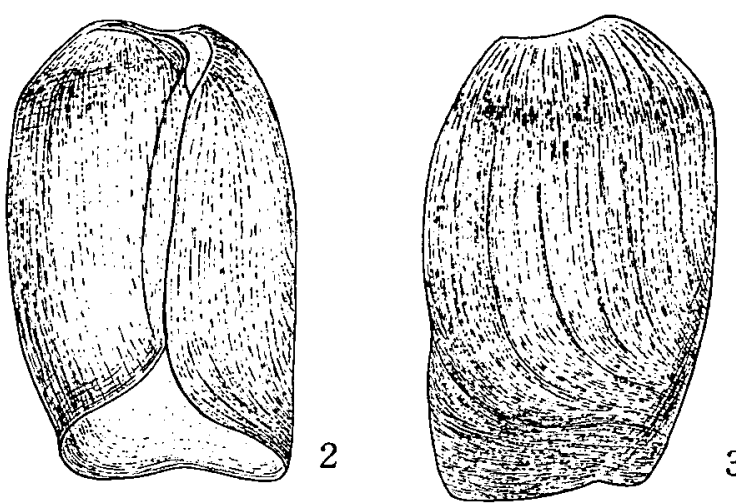

3

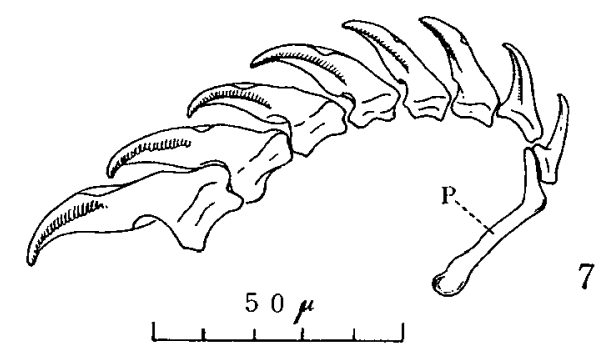

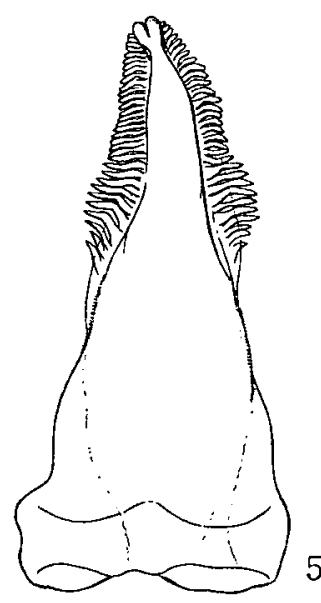

$50 \mu$

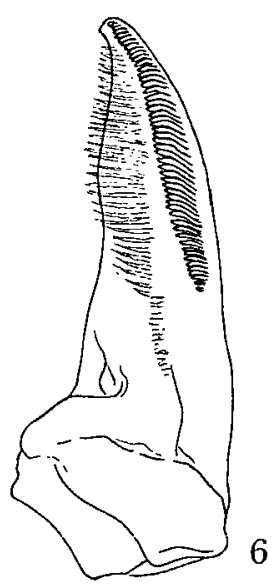

$10 \mu$

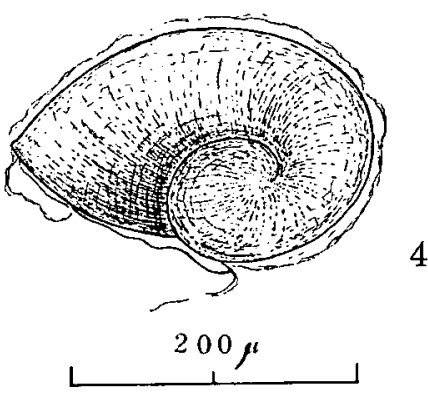

I. Hamatani: A New Shelled Sacoglossan 